\title{
PENILAIAN PENCEMARAN PERAIRAN DI POLDER TAWANG SEMARANG DITINJAU DARI ASPEK SAPROBITAS
}

\author{
Sutrisno Anggoro, Prijadi Soedarsono, Harisya Diah Suprobo*
}

Jurusan Perikanan, Fakultas Perikanan dan Ilmu Kelautan, Universitas Diponegoro

Jl. Prof. H. Soedharto, SH. Tembalang Semarang 50275 Telp/Fax (024) 76480685

\begin{abstract}
Abstrak
Pencemaran air adalah suatu perubahan keadaan disuatu tempat penampungan air seperti danau, sungai, lautan dan air tanah akibat aktivitas manusia. Polder Tawang Semarang merupakan suatu sistem untuk memproteksi air limpahan dari luar kawasan dan mengendalikan muka air di dalam Kota Lama. Polder Tawang Semarang mempunyai masalah pencemaran akibat limbah yang berasal dari limbah kota, pasar ikan, industri, dan rumah tangga yang masuk ke perairan yang berpengaruh terhadap kekeruhan,bau air dan pertumbuhan mikroorganisme.Tujuan dari penelitian ini adalah untuk mengkaji dan mengetahui tingkat saprobitas di Polder Tawang Semarang berdasarkan nilai SI (Saprobik Indeks) dan TSI (Tropik Saprobik Indeks), mengetahui hubungan antara saprobitas perairan dengan variabel kualitas air (BOD dan DO), serta mengetahui tingkat pencemaran air menggunakan penilaian saprobitas perairan. Penelitian ini menggunakan plankton sebagai materi utama yaitu sampel air dan sampel plankton. Komunitas fitoplankton yang terdapat di Polder Tawang Semarang terdapat 14 genera fitoplankton. Berdasarkan nilai kelimpahan individu fitoplankton dengan nilai rata-rata sebesar 8.423- 8.774 ind/L, sedangkan nilai Saprobik Indeks (SI) berkisar $(-0,33)-(0,09)$ dan Tropik Saprobik Indeks berkisar $(-0,67)-(0,14)$ maka tingkat pencemaran di Polder Tawang Semarang selama penelitian diketegorikan sebagai pencemaran sedang sampai berat ( $\alpha$-mesosaprobik). Dari hasil uji regresi antara saprobitas perairan dengan BOD dan DO menunjukkan adanya korelasi yang kuat yang berarti kontribusi pengaruh BOD dan DO terhadap saprobitas cukup besar.
\end{abstract}

Kata kunci : Fitoplankton, Polder Tawang, Saprobik Indeks, Tropik Saprobik Indeks

Abstrak

Water pollution is a change of ambience in a water reservoir, such as lake, river, ocean, and groundwater, affected by human activities. Polder Tawang Semarang is a system protecting the overflow waters comes from surrounding area and controlling the waters level in Kota Lama. Polder Tawang Semarang has pollution issues as the result of wastes from municipal, fish market, industry, and household activity flowing in the waterworks and affecting the turbidity, waters odor and the growth of microorganism. The purposes of this research are to examine and to determine the saprobity level in Polder Tawang Semarang base on the rate of SI (Saprobic Index) and TSI (Tropic Saprobic Index), to determine the relation between the waters saprobity and the variable of waters quality, as well as to determine the waters pollution level on its saprobity.This research used plankton as the main object The result of this research shows that the community of the fitoplanton in Polder Tawang Semarang has 14 genera fitoplanktons. According to the rate of fitoplanktons individual profusion with an average of 8.423- 8.774 ind/L, while the Saprobic Index $(S I)$ is about $(-0,33)-(0,09)$ and the Tropic Saprobic Index (TSI) is about $(-0,67)-(0,14)$, so the pollution level in Polder Tawang Semarang during the research is considered as moderate to heavy pollution ( $\alpha$-mesosaprobik). From the results of the regression test between saprobitas with $B O D$ and DO showed a strong correlation significant contribution to the influence of BOD and DO saprobitas big enough.

Keywords : Phytoplankton, Polder Tawang, Saprobic Index, Tropic Saprobik Index

\section{Pendahuluan}

Polder Tawang Semarang merupakan suatu sistem untuk memproteksi air limpahan dari luar kawasan dan mengendalikan muka air di dalam Kota Lama. Komponen sistem polder ini terdiri dari: tanggul, pintu air, saluran, kolektor, pompa air dan kolam retensi, dengan luas lahan 1 ha. Polder Tawang Semarang merupakan tempat penampungan air yang digunakan untuk mengendalikan banjir, karena sistem perairannya yang tertutup maka air yang masuk kebanyakan berasal dari limbah industri, rumah tangga dan air rob. Air yang masuk akan ditampung, apabila sudah melebihi batas ketentuan daya tampungnya maka akan dipompa keluar keselokan pembuangan. Kondisi kualitas air di Polder Tawang sangat dipengaruhi oleh bahan pencemar yang berasal dari limbah domestik serta industri yang masuk kedalam polder (Seputar Semarang, 2008). 


\section{JOURNAL OF MANAGEMENT OF AQUATIC RESOURCES. \\ Volume 2, Nomor 3, Tahun 2013, Halaman 109-118 \\ Online di : http://ejournal-s1.undip.ac.id/index.php/maquares}

Pada umumnya faktor pemanfaatan suatu perairan antara lain ditentukan oleh tingkat kesuburan perairan, yang dapat diukur dengan kelimpahan produsen primer yang terdapat diperairan tersebut. Produktivitas primer pada dasarnya ditentukan oleh kemampuan suatu perairan untuk dapat mensintesa bahan-bahan organik dari bahan-bahan anorganik yang dilakukan oleh fitoplankton melalui proses fotosintesis. Kelimpahan fitoplankton dalam suatu perairan dipengaruhi keadaan lingkungan yang cukup menunjang sebagai sumber utama suplai pakan bagi organisme didalamnya (Hutabarat, 2000).

Lingkungan dikatakan tercemar apabila sudah tidak sesuai lagi dengan peruntukannya, lingkungan tersebut sudah tidak bisa digunakan lagi sebagai tempat untuk hidup dan berkembang biak oleh makhluk hidup atau lainnya. Polder Tawang Semarang mempunyai masalah pencemaran akibat limbah yang berasal dari limbah kota, pasar ikan, industri, dan rumah tangga yang masuk ke perairan. Limbah ini banyak mengandung senyawa nitrogen yang menjadi sumber nutrisi bagi pertumbuhan mikroorganisme. Selain permasalahan teknis, permasalahan utama lainnya yang dihadapi adalah kekeruhan dan bau perairan yang tidak sedap. Hal ini dikarenakan belum tertanganinya limbah dan sampah domestik yang masuk dalam perairan secara efektif. Berdasarkan hal tersebut, maka perlu dilakukan penelitian lebih lanjut untuk mengetahui seberapa besar tingkat pencemaran di Polder Tawang Semarang .Kelimpahan plankton inilah yang digunakan untuk menentukan nilai saprobitas di Polder Tawang dengan melihat nilai Tropik Saprobik Indeks.

Penelitian ini bertujuan untuk mengkaji dan mengetahui tingkat saprobitas di Polder Tawang Semarang berdasarkan nilai SI (Saprobik Indeks) dan TSI (Tropik Saprobik Indeks), untuk mengetahui hubungan antara saprobitas dengan variabel kualitas air (BOD, DO), serta untuk mengkaji dan mengetahui tingkat pencemaran air menggunakan penilaian saprobitas perairan. Penelitian ini telah dilaksanakan pada bulan Maret - April 2013 di Polder Tawang Semarang dan laboratorium Hidrobiologi jurusan perikanan FPIK, Universitas Diponegoro.

\section{Materi Dan Metode Penelitian}

\section{A. Materi Penelitian}

Materi yang digunakan pada penelitian ini adalah sampel air yang didapat di Polder Tawang. Adapun alat yang digunakan meliputi alat untuk sampling lapangan dan identifikasi plankton. Alat yang digunakan untuk sampling plankton adalah plankton net dengan ukuran 25 mikron, botol sampel, pipet tetes, kertas label, kamera digital, termometer, Secchi disk, DO meter, dan $\mathrm{pH}$ paper. Alat yang digunakan untuk idenfikasi plankton di laboratorium adalah mikroskop, Sedgwick-rafter. Bahan yang digunakan dalam penelitian ini adalah sampel plankton dan air yang didapat dari Polder Tawang Semarang serta "lugol's iodine" untuk pengawetan sampel.

\section{B. Metode}

Metode penelitian yang digunakan dalam penelitian ini adalah metode deskriptif yang bersifat studi kasus. Metode studi kasus yaitu penelitian yang hanya mendalami suatu masalah pada suatu waktu tertentu dan hasil yang didapat belum tentu berlaku pada daerah dan tempat lain walaupun obyek penelitian yang sama.

Pengambilan sampel dilakukan secara sistematik sampling dengan anggapan bahwa keberadaan perairan tersebut dapat terwakili. Menurut Sudjana (1982) sistematik sampling adalah anggota sampel yang diambil dari populasi pada jarak interval waktu, ruang atau urutan yang seragam (uniform) dengan anggapan bahwa pada daerah yang padat dan jarang dapat terwakili. Pengambilan sampel plankton dilakukan dengan penyaringan (filtration method) dengan cara menyaring air polder sebanyak 100 liter yang diambil dengan menggunakan ember 10 liter dan disaring menggunakan plankton net no. 25

Lokasi pengambilan sampel ini dilakukan di Polder Tawang Semarang. Pengambilan sampel air dilakukan pada pinggir-pinggir polder dengan kedalaman 1m, dikarenakan pada kedalaman tersebut memungkinkan kelimpahan fitoplankton tinggi. Pengambilan sampel dilakukan pada 5 titik stasiun pada pagi dan sore hari dengan interval waktu 2 minggu.

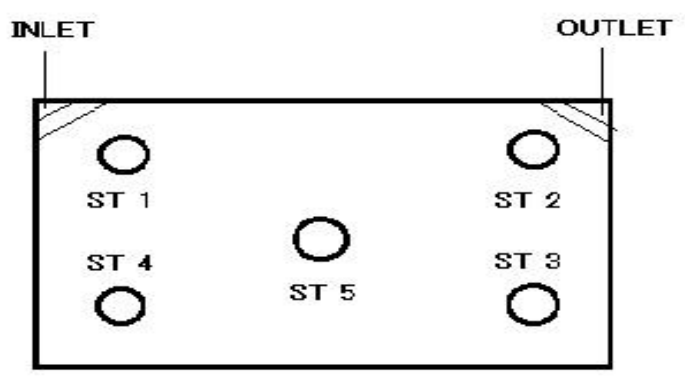

Gambar 1. Penentuan Titik Sampling di Polder Tawang Semarang 


\section{Analisis Data}

Identifikasi organisme plankton dilakukan dengan menggunakan mikroskop binokuler perbesaran 10x10. Pengamatan dan perhitungan organisme dilakukan dengan bantuan Sedgwick-rafter. Pengidentifikasian plankton dengan menggunakan buku identifikasi Sachlan (1982) dan Davis (1955). Setelah dilakukan identifikasi jenis-jenis plankton dilakukan perhitungan untuk mencari nilai kelimpahan jenis, Indeks Keanekaragaman, Indeks Kemerataan, Indeks Dominansi, Saprobik Indeks dan Tropik Saprobik Indeks.

\section{Kelimpahan Fitoplankton}

Perhitungan kelimpahan fitoplankton per liter dilakukan dengan menggunakan formulasi APHA (1992), yaitu

$$
N=\frac{T}{L} \times \frac{P}{p} \times \frac{V}{v} \times \frac{1}{W}
$$

Keterangan :

$\mathrm{N}=$ jumlah plankton per liter

$\mathrm{T}=$ luas total petak Sedgwick-rafter $\left(1000 \mathrm{~mm}^{2}\right)$

$\mathrm{L} \quad=$ luas lapang pandang mikroskop $\left(\mathrm{mm}^{2}\right)$

$\mathrm{W}=$ volume sampel air yang tersaring $(\mathrm{L})$

$\mathrm{p}=$ jumlah lapang pandang yang diamati

$\mathrm{V}=$ volume sampel plankton yang tersaring $(\mathrm{ml})$

$\mathrm{v}=$ volume sampel plankton dalam Sedgwick-rafter

$\mathrm{P}=$ jumlah plankton tercacah

\section{Indeks Keanekaragaman}

Analisa ini digunakan untuk mengetahui keanekaragaman jenis biota perairan. Persamaan yang digunakan untuk menghitung indeks ini adalah persamaan Shanon-Wiener:

$$
H^{\prime}=-\sum \mathrm{Pi} \ln \mathbf{P i}
$$

Keterangan:

$$
\begin{aligned}
& \mathrm{H}^{\prime}=\text { indeks diversitas Shanon-Wiener } \\
& \mathrm{Pi}=\text { ni/N } \\
& \mathrm{ni}=\text { jumlah individu jenis ke-i } \\
& \mathrm{N}=\text { jumlah total individu }
\end{aligned}
$$

Berdasarkan indeks keanekaragaman juga dapat ditentukan kriteria mutu kualitas perairan. Apabila indeks keanekaragaman $>3$ berarti perairan tidak tercemar. Perairan termasuk tercemar sedang bila H' dalam kisaran 1 - 3 . Yang terakhir perairan termasuk tercemar berat bila $\mathrm{H}^{\prime}<1$ (Dahuri dalam Wibowo 2004).

\section{Indeks Keseragaman}

Indeks ini menunjukan pola sebaran biota, yaitu merata atau tidak. Jika nilai indeks keseragaman relatif tinggi maka keberadaan setiap jenis biota di perairan dalam kondisi merata. Analisa indeks keseragaman fitoplankton menggunakan rumus sebagai berikut (Odum, 1971):

$$
\text { e }=\frac{H^{\prime}}{\text { Hmaks }}
$$

Keterangan:

$$
\begin{array}{ll}
\mathrm{e} & =\text { Indeks keanekaragaman } \\
\mathrm{H} \text { maks } & =\text { In S (S adalah jumlah genera }) \\
\mathrm{H}^{\prime} & =\text { Indeks keanekaragaman }
\end{array}
$$

\section{Indeks Dominansi}

Menurut Odum (1971), untuk mengetahui adanya dominasi tertentu di perairan dapat digunakan indeks dominasi dengan persamaan berikut:

Keterangan:

$$
D=\left(\frac{n i}{N}\right)^{2}
$$

D = Indeks dominasi

ni $=$ jumlah individu tiap spesies

$\mathrm{N} \quad=$ Total individu 


\section{JOURNAL OF MANAGEMENT OF AQUATIC RESOURCES. \\ Volume 2, Nomor 3, Tahun 2013, Halaman 109-118 \\ Online di : http://ejournal-s1.undip.ac.id/index.php/maquares}

Saprobik Indeks (SI) dan Tropik Saprobik Indeks (TSI)

Untuk menghitung saprobitas perairan digunakan analisis TROSAP yang nilainya ditentukan dari hasil formulasi Persone dan De Pauw (1983) dalam Anggoro (1988):

$$
S I=\frac{1 C+3 D+1 B-3 A}{1 A+1 B+1 C+1 D}
$$

Keterangan:

A = Jumlah Spesies Organisme Polisaprobik

$\mathrm{B}=$ Jumlah Spesies Organisme $\alpha$-Mesosaprobik

C = Jumlah Spesies Organisme $\beta$-Mesosaprobik

$\mathrm{D}=$ Jumlah Spesies Organisme Oligosaprobik

$$
\mathrm{TSI}=\frac{1(\mathrm{nC})+3(\mathrm{nD})+(\mathrm{nB})-\mathbf{3}(\mathrm{nA})}{1(\mathrm{nA})+1(\mathrm{nB})+1(\mathrm{nC})+1(\mathrm{nD})} \times \frac{\mathrm{nA}+\mathrm{nB}+\mathrm{nC}+\mathrm{nD}+\mathrm{nE}}{\mathrm{nA}+\mathrm{nB}+\mathrm{nC}+\mathrm{nD}}
$$

Keterangan:

$\mathrm{N}=$ Jumlah individu organisme pada setiap kelompok saprobitas

$\mathrm{nA}=$ Jumlah individu penyusun kelompok Polisaprobik

$\mathrm{nB}=$ Jumlah individu penyusun kelompok $\alpha$-Mesosaprobik

$\mathrm{nC}=$ Jumlah individu penyusun kelompok $\beta$-Mesosaprobik

$\mathrm{nD}=$ Jumlah individu penyusun kelompok Oligosaprobik

$\mathrm{nE}=$ Jumlah individu penyusun selain A, B,C dan D

\section{Hipotesis Penelitian}

Untuk mengetahui hubungan antar dua variabel menggunakan metode korelasi dan regresi sederhana

$\mathrm{H}_{0} \quad$ : Tidak terdapat hubungan antara saprobitas perairan dengan variabel BOD dan DO.

$\mathrm{H}_{1} \quad$ : Terdapat hubungan antara saprobitas perairan dengan BOD dan DO.

Secara umum hubungan yang sering digunakan adalah sebagai berikut :

\section{Hasil dan Pembahasan}

\section{Gambaran umum lokasi penelitian}

Polder Tawang Semarang merupakan tempat penampungan air yang digunakan untuk mengendalikan banjir, karena sistem perairannya yang tertutup maka air yang masuk kebanyakan berasal dari limbah industri, rumah tangga dan air rob. Air yang masuk akan ditampung, apabila sudah melebihi batas ketentuan daya tampungnya maka akan dipompa keluar keselokan pembuangan. Kondisi kualitas air di Polder Tawang sangat dipengaruhi oleh bahan pencemar yang berasal dari limbah domestik serta industri yang masuk kedalam polder (Seputar Semarang, 2008).

Polder Tawang terletak didepan stasiun kereta api Tawang Semarang, mempunyai luas pelayanan 19 Ha dan luas kolam retensinya $1 \mathrm{Ha}$. Kedalaman kolam retensi $4 \mathrm{~m}$ dengan kedalaman efektif 2-3 m. Polder Tawang mempunyai kapasitas daya tampung air sebesar 20.000-30.000 $\mathrm{m}^{3}$ dengan kapasitas lumpur 5000-10.000 $\mathrm{m}^{3}$. Polder Tawang Semarang dibangun secara permanen dengan bentuk segiempat dan kondisi dinding berundak, setiap undakannya mempunyai tinggi $30 \mathrm{~cm}$ dengan dasar semen (Dinas Pengairan Kota Semarang, 2006).

\section{Kelimpahan Fitoplankton}

Dari hasil identifikasi sampel fitoplankton yang dijumpai di Polder Tawang Semarang berjumlah 14 genera. Kelimpahan rata-rata fitoplankton pada pagi hari sebesar 8.423-8.774 ind/L dan pada sore hari sebesar 8.550-8.716

\begin{tabular}{|c|c|c|c|c|c|c|}
\hline No & Genus & $\mathrm{I}$ & II & III & IV & $\mathrm{V}$ \\
\hline A. & Polysaprobik & & & & & \\
\hline 1. & Spirulina sp & 229 & 312 & 159 & 159 & 312 \\
\hline 2. & Euglena $\mathrm{sp}$ & 516 & 516 & 407 & 1433 & 637 \\
\hline 3. & Chlorobacterium $\mathrm{sp}$ & 1433 & 312 & 1840 & 2063 & 516 \\
\hline B. & $\alpha$-Mesosaprobik & & & & & \\
\hline 1. & Oscillatoria $\mathrm{sp}$ & 159 & 312 & 102 & 101 & - \\
\hline 2. & Closterium $\mathrm{sp}$ & 516 & 1841 & 3082 & 159 & 407 \\
\hline 3. & Nitzschia $\mathrm{sp}$ & 3089 & 3980 & 1076 & 3.981 & 3368 \\
\hline C. & $\beta$-Mesosaprobik & & & & & \\
\hline 1. & Asterionella $\mathrm{sp}$ & 57 & 25 & - & - & 57 \\
\hline 2. & Melosira $\mathrm{sp}$ & 1273 & 312 & 516 & 159 & 917 \\
\hline 3. & Paramecium sp & 1076 & 637 & 917 & 102 & 2063 \\
\hline 4. & Actinosphaerium sp & 159 & 159 & 312 & 159 & 229 \\
\hline D. & Olygosaprobik & & & & & \\
\hline 1. & Cyclotella $\mathrm{sp}$ & 57 & 57 & - & 57 & 25 \\
\hline E. & Lain-lain & & & & & \\
\hline 1. & Fragillaria $\mathrm{sp}$ & 57 & 229 & 57 & 25 & 57 \\
\hline 2. & Spyrugira sp & 57 & 25 & 25 & 25 & - \\
\hline 3. & Navicula $\mathrm{sp}$ & 25 & 57 & 25 & - & - \\
\hline & Jumlah & 8703 & 8774 & 8518 & 8423 & 8588 \\
\hline
\end{tabular}
ind/L. 
Tabel 2. Kelimpahan Fitolankton di Polder Tawang pada Sore Hari (ind/L)

\begin{tabular}{llllllc}
\hline No & \multicolumn{1}{c}{ Genus } & I & II & III & IV & V \\
\hline A. & Polysaprobik & & & & & \\
1. & Spirulina sp & 229 & 159 & 159 & 57 & - \\
2. & Euglena sp & 159 & 407 & 1076 & 57 & 637 \\
3. & Chlorobacterium sp & 516 & 1076 & 1248 & 312 & 1076 \\
B. & a-Mesosaprobik & & & & & \\
1. & Oscillatoria sp & 407 & 102 & 229 & 25 & 312 \\
2. & Closterium sp & 917 & 407 & 229 & 917 & 917 \\
3. & Nitzschia sp & 3668 & 3981 & 3082 & 3083 & 4305 \\
C. & B-Mesosaprobik & & & & & \\
1. & Melosira sp & 159 & 407 & 312 & 25 & 407 \\
2. & Paramecium sp & 159 & 159 & 229 & 1630 & 229 \\
3. & Scenedesmus sp & 2063 & 1248 & 1248 & 2299 & 159 \\
4. & Actinosphaerium sp & - & 102 & 25 & - & - \\
D. & Olygosaprobik & & & & & \\
1. & Cyclotella sp & 57 & 102 & 312 & - & 229 \\
E. & Lain-lain & & & & & \\
1. & Fragillaria sp & 57 & 407 & 312 & 159 & 57 \\
2. & Spyrugira sp & 159 & 159 & 159 & 102 & 312 \\
\hline & Jumlah & 8550 & 8716 & 8620 & 8564 & 8640 \\
\hline
\end{tabular}

Berdasarkan data diatas dapat diketahui bahwa jenis plankton yang banyak ditemukan pada pagi dan sore hari adalah Nitzschia sp. Genus fitoplankton ini termasuk dalam kelas Bacillariphyceae. Menurut Nybakken (1992), jenis ini mampu tumbuh dengan cepat meskipun pada kondisi nitrient dan cahaya yang rendah. Selain itu fitoplankton dari kelas ini juga mampu meregenerasi dan reproduksi yang lebih besar juga memiliki kemampuan untuk bereproduksi yang tinggi, sehingga jumlahnya lebih mendominasi dibanding genus yang lain.

\section{Variabel kualitas air}

Hasil pengukuran variabel kualitas air selama penelitian yang didapat di Polder Tawang, didapatkan data kisaran rata-rata kualitas air seperti tersaji dalam tabel 3 sebagai berikut:

Tabel 3. Hasil Pengukuran Variabel Kualitas Air di Polder Tawang

\begin{tabular}{|c|c|c|c|c|c|c|c|}
\hline \multirow[t]{2}{*}{ Parameter } & \multicolumn{5}{|c|}{ Stasiun } & \multirow{2}{*}{$\begin{array}{c}\text { Kisaran } \\
\text { Optimum }\end{array}$} & \multirow[t]{2}{*}{ Pustaka } \\
\hline & 1 & 2 & 3 & 4 & 5 & & \\
\hline Suhu air $\left({ }^{\circ} \mathrm{C}\right)$ & $31-32$ & $31-32$ & $31-32$ & $31-32$ & $31-32$ & $26-34$ & Kep-51/Men KLH/2004 \\
\hline $\mathrm{pH}$ & $8-9$ & $8-9$ & $8-9$ & $8-9$ & $8-9$ & $6,5-9$ & (Boyd,1991) \\
\hline Kedalaman $(\mathrm{cm})$ & 100 & 100 & 100 & 100 & 100 & & \\
\hline Kecerahan (cm) & $41-42$ & $41-42$ & $40-41$ & $40-41$ & $41-42$ & & \\
\hline $\mathrm{DO}(\mathrm{mg} / \mathrm{L})$ & $2,75-2,85$ & $2,65-2,7$ & $2,36-2,56$ & $2,33-2,5$ & $2,84-2,68$ & $>5$ & Kep-51/Men KLH/2004 \\
\hline Nitrat (mg/L) & $0,26-0,52$ & $0,25-0,44$ & $0,76-0,31$ & $0,82-0,42$ & $0,38-0,26$ & $0,9-3,5$ & Wardoyo (1982) \\
\hline Fosfat (mg/L) & $0,38-0,52$ & $0,23-0,40$ & $0,60-0,39$ & $0,78-0,25$ & $0,39-0,24$ & $0,27-5,51$ & Wardiyatmo (1990) \\
\hline $\mathrm{BO}(\mathrm{mg} / \mathrm{L})$ & $210-310$ & $224-298$ & $428-232$ & $514-277$ & $243-218$ & & \\
\hline $\mathrm{BOD}(\mathrm{mg} / \mathrm{L})$ & $9,04-9,82$ & $9,33-9,57$ & $10,15-11,03$ & $11,35-11,02$ & $9,29-9,47$ & 10 & Kep.Men LH 51/2004 \\
\hline
\end{tabular}

\section{Indeks Saprobitas dan Tropik Saprobik Indeks}

Dari hasil penelitian yang dilakukan di Polder Tawang Semarang didapatkan nilai saprobitas perairan yang tersaji pada tabel 5.

Tabel 4. Nilai Indeks Saprobitas dan Tropik Saprobik Indeks (TSI)

\begin{tabular}{ccccc}
\hline \multirow{2}{*}{ Stasiun } & \multicolumn{2}{c}{ Indeks Saprobitas } & \multicolumn{2}{c}{ TSI } \\
\cline { 2 - 5 } & Pagi & Sore & Pagi & Sore \\
\hline I & 0,09 & 0 & $-0,05$ & 0,24 \\
II & 0,09 & 0,09 & 0,14 & $-0,011$ \\
III & $-0,33$ & 0,09 & $-0,25$ & $-0,13$ \\
IV & 0 & $-0,33$ & $-0,67$ & 0,42 \\
V & 0 & 0,33 & 0,11 & 0,16 \\
\hline
\end{tabular}




\section{JOURNAL OF MANAGEMENT OF AQUATIC RESOURCES. Volume 2, Nomor 3, Tahun 2013, Halaman 109-118 \\ Online di : http://ejournal-s1.undip.ac.id/index.php/maquares}

\section{Pembahasan}

\section{Kelimpahan fitoplankton}

Hasil identifikasi dan perhitungan fitoplankton yang didapatkan pada saat penelitian ditemukan 14 genus dan yang paling mendominasi adalah genus dari kelas Bacillariphyceae yaitu Nitzchia sp. Menurut Nybakken (1992), jenis ini mampu tumbuh dengan cepat meskipun pada kondisi nitrient dan cahaya yang rendah. Selain itu fitoplankton dari kelas ini juga mampu meregenerasi dan reproduksi yang lebih besar juga memiliki kemampuan untuk bereproduksi yang tinggi, sehingga jumlahnya lebih mendominasi dibanding genus yang lain.

Populasi plankton di Polder Tawang dalam kurun waktu 4 minggu, setiap minggunya berbeda. Menurut Basmi (2000), populasi plankton pada tempat dan waktu tertentu tergantung pada laju reproduksi dari masing-masing individu didalamnya dan karena kematian. Davis (1955) menyatakan bahwa dalam suatu penelitian, plankton sering dijumpai perbedaan baik jenis maupun jumlahnya pada daerah yang berdekatan, meskipun berasal dari massa air yang sama. Hal ini seperti pada lokasi penelitian pada beberapa stasiun didapatkan fitoplankton yang melimpah namun pada stasiun didekatnya kandungan planktonnnya sedikit.

Faktor fisika kimia perairan serta masuknya bahan-bahan pencemar yang berasal dari limbah industri maupun domestik akan mempengaruhi perubahan lingkungan dan daya toleransi plankton. Sehingga sebagian jumlah plankton yang menguntungkan bagi kesuburan perairan akan mati, khususnya jenis plankton yang tidak tahan terhadap perubahan lingkungan. Oleh karena itu jenis plankton yang tahan terhadap perubahan lingkungan yang akan mendominasi perairan tersebut.

Kelimpahan individu fitoplankton di Polder Tawang berkisar antara 8.423-8.774 individu/l. Kelimpahan individu tertinggi ada pada stasiun II. Tingginya kelimpahan fitoplankton di stasiun II disebabkan karena tingginya kandungan nutrien yang terdapat pada stasiun tersebut yang terletak pada daerah outlet. Ketersediaan unsur hara sangat berpengaruh terhadap komunitas plankton.

Hasil analisis indeks keanekaragaman ( $\left.\mathrm{H}^{\prime}\right)$ pada kelima stasiun adalah 1,4-1,88 pada pagi hari dan 1,57-1,84 pada sore hari. Terlihat bahwa komunitas fitoplankton berada dalam kondisi rendah. Menurut Wilhm dan Doris (1968) dalam Dianthani (2003) bahwa nilai $\mathrm{H}^{\prime}<2,3026$ menandakan keanekaragaman kecil dan kestabilan komunitas rendah. Sedangkan nilai indeks keseragaman (e) rata-rata adalah 0,73-0,87 pada pagi hari dan 0,85-0,94 pada sore hari atau mendekati nilai 1, yang berarti bahwa keseragaman antar spesies relatif merata. Hal ini disebabkan karena tidak terdapat spesies yang mendominasi spesies lainnya. Menurut Basmi (2000) nilai indeks keseragaman mendekati 1 menandakan keseragaman antar spesies dapat dikatakan merata atau jumlah individu pada masing-masing spesies hampir sama Basmi (2000). Sedangkan menurut Wibowo (2004), keanekaragaman jenis tinggi apabila banyak spesies berada di suatu komunitas tersebut, dan nilai keanekaragaman akan rendah bila satu atau beberapa jenis saja yang terdapat di dalamnya dan mendominasi daerah tersebut.

\section{Variabel kualitas air}

Berdasarkan hasil pengukuran parameter fisika kimia yang diperoleh dari kelima stasiun baik pagi maupun sore hari nilai rata-ratanya masih memenuhi kisaran optimum bagi pertumbuhan organisme. Namun ada beberapa parameter seperti $\mathrm{pH}$, nitrat yang berada dibawah kisaran optimum, hal ini sangat berpengaruh terhadap keanekaragaman, kelimpahan dan keseragaman fitoplankton pada daerah tersebut yang akan mempengaruhi saprobitasnya.

Hasil analisis regresi linear antara saprobitas perairan dengan suhu perairan yang diperoleh mempunyai model dan kurva linier seperti pada gambar 2 dibawah.

Hubungan antara kelimpahan fitoplankton dengan suhu berkorelasi linier negatif dengan keeratan hubungan 0,7080 atau korelasinya kuat dan koefisien determinasi sebesar 50,13\%. Hal ini menunjukkan bahwa suhu merupakan salah satu faktor yang berperan penting dalam kehidupan dan petumbuhan organisme perairan termasuk fitoplankton. Didalam perairan suhu mempengaruhi aktivitas fotosintesis dan kelarutan gas-gas (Boney,1978). Dari hasil pengukuran suhu pada kelima stasiun yang diperoleh sebesar $31-32^{\circ} \mathrm{C}$. Kisaran suhu tersebut masih dapat ditolerir bagi kelangsungan hidup dan pertumbuhan fitoplankton. Hal ini sesuai dengan Hutabarat dan Evans, 1986 yang mengungkapkan bahwa suhu air optimum rata-rata berkisar antara $24-32^{\circ} \mathrm{C}$ pada kisaran tersebut plankton dapat tumbuh dan berkembang biak dengan baik.

Kedalaman perairan merupakan faktor lingkungan yang mempengaruhi penyebaran fitoplankton. Kedalaman ratarata yang diukur pada setiap stasiun adalah $100 \mathrm{~cm}$, nilai kedalaman ini masih memenuhi batas normal utuk tempat hidup fitoplankton. Menurut Hutabarat (2000), kedalaman perairan terkait erat dengan penetrasi cahaya yang masuk didalam perairan. Penyinaran matahari akan berkurang seiring dengan bertambhanya kedalaman. Sedangkan nilai kecerahan yang diperoleh pada kelima stasiun berkisar antara 40-42 cm. Kecerahan terendah terdapat pada stasiun 4 , menurut pengamatan pada saat penelitan pada stasiun terdapat banyak tumpukan sampah serta tertutup oleh lumut. Hal ini juga dijumpai pada saat pengamatan pada sedgewick rafter bahwa sampel airnya berwarna keruh dan berbau menyengat. Kecerahan perairan berperan penting dalam produktifitas primer perairan. Hal ini sesuai dengan pernyataan Brown dalam Lilik (2005) bahwa cahaya merupakan faktor penting karena berdampak langsung terhadap distribusi dan 


\section{JOURNAL OF MANAGEMENT OF AQUATIC RESOURCES. Volume 2, Nomor 3, Tahun 2013, Halaman 109-118 \\ Online di : http://ejournal-s1.undip.ac.id/index.php/maquares}

jumlah organisme khususnya fitoplankton dalam badan air. Semakin sedikit cahaya yang masuk akan menurunkan aktifitas fotosintesa fitoplankton yang berakibat menurunnya produktifitas perairan.

Hasil analisis regresi linear antara saprobitas perairan dengan kecerahan perairan yang diperoleh mempunyai model dan kurva linier seperti terlihat pada gambar 3.

Hubungan antara kelimpahan fitoplankton dengan kecerahan berkorelasi linier negatif dengan keeratan hubungan 0,8651 atau korelasinya kuat dan koefisien determinasi sebesar 74,84\%. Hal ini menunjukkan bahwa kontribusi pengaruh kecerahan terhadap kehidupan fitoplankton cukup besar.

Nilai pH yang diperoleh dari kelima stasiun adalah 8-9 dan masih memenuhi batas optimal untuk pertumbuhan fitoplankton. Hasil analisis regresi linear antara kelimpahan fitoplankton dengan $\mathrm{pH}$ yang diperoleh mempunyai model dan kurva linier seperti terlihat pada gambar 4.

Hubungan antara kelimpahan fitoplankton dengan pH berkorelasi kuat dengan keeratan hubungan 0,7080 dan koefisien determinasi sebesar 50,13\%. Hal ini menunjukkan bahwa kontribusi pengaruh pH terhadap kehidupan fitoplankton cukup besar.

Menurut Odum (1971), perairan dengan pH antara 6 - 9 merupakan perairan dengan kesuburan yang tinggi dan tergolong produktif karena memiliki kisaran $\mathrm{pH}$ yang dapat mendorong proses pembongkaran bahan organik yang ada dalam perairan menjadi mineral-mineral yang dapat diasimilasikan oleh fitoplankton.

Oksigen terlarut (DO) yang diperoleh pada saat penelitian berkisar antara 2,33-2,84 mg/L. Hasil analisis regresi linear antara kelimpahan fitoplankton dengan kandungan oksigen terlarut yang diperoleh mempunyai model dan kurva linier seperti terlihat pada gambar 5 .

Hubungan antara kelimpahan fitoplankton dengan oksigen terlarut secara linier menunjukkan hubungan dengan tingkat keeratan sebesar 0,76 atau korelasinya kuat dengan koeefisien determinasi sebesar 58,91\%. Adanya keeratan hubungan secara linier yang kuat ini menjelaskan bahwa kandungan oksigen terlarut didalam suatu perairan akan mempengaruhi kehidupan fitoplankton. Berdasarkan hasil pengukuran menunjukkan bahwa nilai oksigen terlarut dilokasi perairan rendah. Hal ini diakibatkan karena banyaknya bahan-bahan pencemar yang mengakibatkan penurunan kandungan oksigen. Menurut Afrianto dan Liviawati (1994) kandungan oksigen optimum dalam suatu perairan untuk dapat mendukung kehidupan organisme berkisar antara 4-8 mg/L.

Effendi dalam Anjas (2005) sumber utama oksigen dalam periran adalah dari proses fotosintesis. Semakin subur suatu perairan akan semakin banyak fitoplankton yang hidup didalamnya dan akhirnya akan meningkatkan pasokan oksigen terlarut dalam air. Adanya kandungan oksigen terlarut yang rendah disebabkan karena aktifitas respirasi yang lebih tinggi daripada fotosintesis. Selain itu nilai yang rendah tersebut diduga karena tingginya aktifitas respirasi oleh organisme air serta adanya proses dekomposisi aerob oleh bakteri. Hal ini sesuai dengan tingginya BOD yang terdapat pada stasiun 4 yang memiliki DO paling rendah dibanding stasiun yang lain.

Nilai BOD selama pengamatan di Polder Tawang Semarang memiliki kisaran nilai 9,04-11,35 mg/l. Hubungan antara kelimpahan fitoplankton dengan BOD secara linier menunjukkan adanya pengaruh terhadap kelimpahan fitoplankton dengan tingkat keeratan sebesar 0,71 dan koeefisien determinasi sebesar 51,37\%. Nilai tertinggi terdapat pada stasiun 4 sebesar 11,35 mg/l. Menurut Keputusan Menteri Lingkungan Hidup No.51 Tahun 2004 bahwa kisaran BOD maksimal adalah $10 \mathrm{mg} / \mathrm{L}$. Besarnya nilai BOD pada stasiun 4 ini diduga karena banyaknya limbah yang tertumpuk sehingga menyebabkan penetrasi cahaya matahari yang masuk terganggu, terlihat bahwa warna air yang keruh dan berbau menyengat. Hal ini sesuai dengan pernyataan Effendi (2003) bahwa BOD dapat menggambarkan jumlah bahan organik yang dapat didekomposisi secara biologi dan bahan organik tersebut berasal dari pembusukan tumbuhan dan hewan yang telah mati atau merupakan hasil buangan limbah domestik dan industri. Sedangkan hasil pengukuran bahan organik di Polder Tawang berkisar antara 210-514 \%, tertinggi pada stasiun 4. Hasil analisis regresi linear antara kelimpahan fitoplankton dengan kandungan BOD yang diperoleh mempunyai model dan kurva linier seperti terlihat pada gambar 6.

Hasil analisis regresi linear antara kelimpahan fitoplankton dengan kandungan bahan organik yang diperoleh mempunyai model dan kurva linier seperti terlihat pada gambar 7 .

Berdasarkan hasil analisa laboratorium yang diperoleh kisaran kandungan nitrat pada saat penelitian adalah 0,260,82 mg/L. Hasil analisis regresi linear antara kelimpahan fitoplankton dengan kandungan nitrat yang diperoleh mempunyai model dan kurva linier seperti terlihat pada gambar 8 .

Hubungan antara kelimpahan fitoplankton dengan nitrat secara linier berkorelasi negatif dengan tingkat keeratan sebesar 0,859 atau berkorelasi kuat. Dan koefien determinasi sebesar 73,87\%. Adanya keeratan hubungan secara linier yang kuat ini menjelaskan bahwa kandungan nitrat didalam suatu perairan akan mempengaruhi kehidupan fitoplankton. Hubungan antara kelimpahan fitoplankton dengan nitrat berkorelasi negatih hal ini diduga karena kandungan nitrat masih dalam batas yang dapat ditolerir untuk kehidupan fitoplankton. Hal ini sesuai dengan pernyataan Wardoyo (1982) bahwa konsentrasi dibawah $0,01 \mathrm{mg} / \mathrm{L}$ atau diatas $4,5 \mathrm{mg} / \mathrm{L}$ nitrat dapat menjadi faktor pembatas dalam suatu perairan. Selain iti kandungan nitrat yang tendah dipengaruhi oleh faktor fisika dan kimia 


\section{JOURNAL OF MANAGEMENT OF AQUATIC RESOURCES. Volume 2, Nomor 3, Tahun 2013, Halaman 109-118 \\ Online di : http://ejournal-s1.undip.ac.id/index.php/maquares}

perairan seperti oksigen terlarut. Kandungan oksigen terlarut akan mempengaruhi kandungan unsur hara perairan khususnya nitrat, dimana kelarutan oksigen berpengaruh terhadap proses metabolisme fitoplankton. Proses metabolisme fitoplankton akan banyak memanfaatkan unsur hara seperti nitrat. Kandungan nitrat yang rendah juga disebabkan oleh tingginya kemampuan fitoplankton dalam menyerap nitrat.

Hasil analisis regresi linear antara kelimpahan fitoplankton dengan fosfat yang diperoleh mempunyai model dan kurva linier seperti terlihat pada gambar 9.

Hubungan antara kelimpahan fitoplankton dengan fosfat secara linier berkorelasi negatif dengan tingkat keeratan sebesar 0,781 atau berkorelasi kuat dan koefien determinasi sebesar $61,06 \%$. Adanya keeratan hubungan secara linier yang kuat ini menjelaskan bahwa kandungan fosfat didalam suatu perairan akan mempengaruhi kehidupan fitoplankton. Nilai kisaran fosfat yang didapat di Polder tawang Semarang adalah 0,23-0,78. Nilai kisaran fosfat ini masih memenuhi batas optimum untuk pertumbuhan organisme. Hal ini sesuai dengan pernyataan Supriharyono (1978) bahwa fosfat yang dibutuhkan untuk pertumbuhan algae berkisar antara 0,09-1,8 mg/L.

Keberadaan fosfor secara berlebihan yang diimbangi dengan keberadaan nitrogen menstimulir ledakan algae (blooming algae). Algae yang berlimpah ini membentuk lapisan yang menutupi perairan selanjutnya menghambat penetrasi cahaya dan oksigen. Hal ini terlihat pada stasiun 4 memiliki kandungan fosfor tertinggi namun kandungan oksigen terlarutnya paling rendah dibanding stasiun yang lain.

\section{Indeks Saprobitas (SI) dan Tropik Saprobik Indeks (TSI)}

Berdasarkan tabel 4 nilai SI dan TSI dapat diketahui bahwa kondisi perairan di Polder Tawang Semarang termasuk kategori tercemar sedang sampai berat. Nilai SI pada pagi hari berkisar antara - $0,33-0,25$ sedangkan pada sore hari adalah -0,11-0,33. Kisaran nilai saprobitas tersebut berdasarkan hasil pengamatan termasuk dalam golongan $\alpha-$ Mesosaprobik. Menurut Lee at al (1978) dalam Anggoro (1988), suatu perairan dengan nilai SI dan TSI -2 sampai 0,5 tergolong dalam kelompok $\alpha$-Mesosaprobik. Adanya perbedaan nilai saprobitas pada setiap stasiun dipengaruhi oleh sifat fisik dan kimia perairan yang akan berpengaruh terhadap organisme saprobik baik langsung maupun tidak langsung. Variabel kualiatas airyang mempengaruhi besar kecilnya nilai indeks saprobitas antara lain BOD dan oksigen terlarut. Hasil analisis regresi antara BOD dan DO dengan saprobitas perairan dapat dilihat pada gambar 10 dan gambar 11.

Hubungan antara indeks saprobitas dengan BOD menunjukkan adanya korelasi negatif dengan keeratan hubungan sebesar 0,7963 dan koefisien determinasi sebesar 63,41\%. Hal ini menunjukkan bahwa kontribusi BOD memberikan pengaruh cukup besar terhadap saprobitas perairan.

Hubungan antara indeks saprobitas dengan DO menunjukkan adanya korelasi positif dengan keeratan hubungan sebesar 0,7889 atau korelasinya kuat dan koefisien determinasi sebesar 62,24\%. Hal ini menunjukkan bahwa kontribusi DO memberikan pengaruh cukup besar terhadap saprobitas perairan.

Zahidin (2008) mengemukakan tingkat saprobik di perairan yang menunjukkan tingkat pencemaran sedang sampai berat tersebut disebabkan oleh bahan pencemar organik dan anorganik. Dari hasil penelitian diketahui bahwa kandungan bahan organik, dan BOD di stasiun 4 tertinggi dibanding stasiun lain. Tingginya nilai BOD menunjukkan indikasi kurang mampunya perairan memenuhi kebutuhan oksigen bagi organisme air atau perairan tersebut tercemar. Kondisi ini disebabkan banyaknya masukan bahan pencemar dari bahan organik maupun anorganik. Salah satu buktinya nilai kandungan BOD pada stasiun 4 melebihi baku mutu berdasarkan Keputusan Menteri Lingkungan Hidup Nomor 51 tahun 2004. Tingginya aktivitas domestik seperti pemukiman serta industri menghasilkan buangan limbah organik maupun anorganik yang masuk kedalam polder sehingga mengurangi kadar oksigen dalam air yang mempengaruhi nilai indeks saprobitasnya.

Nilai saprobitas perairan merupakan gambaran tingkat pencemaran suatu perairan yang diukur dari kandungan nutrien dan bahan pencemar. Kandungan nutrien yang cukup akan meningkatkan produktivitas fitoplankton sehingga akan mempengaruhi kelimpahannya (Suryanti, 2008).

Pringgosaputro (1993) menjelaskan bahwa keberadaan organisme saprobitas sebagai landasan indikator suatu perairan juga ditentukan oleh kualitas air lingkungan perairan. Tiap jenis organisme saprobitas akan menempati perairan tertemtu yang keberadaannya ditentukan oleh kualitas air yaitu sifat fisika dan kimia perairan. Sifat fisika seperti kecerahan, kedalaman, suhu perairan akan mempengaruhi kehidupan organisme saprobitas baik secara langsung maupun tidak langsung. 


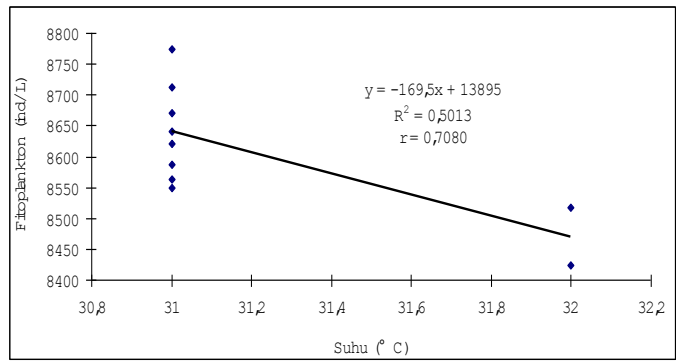

Gambar 2. Regresi linier antara fitoplankton dengan suhu

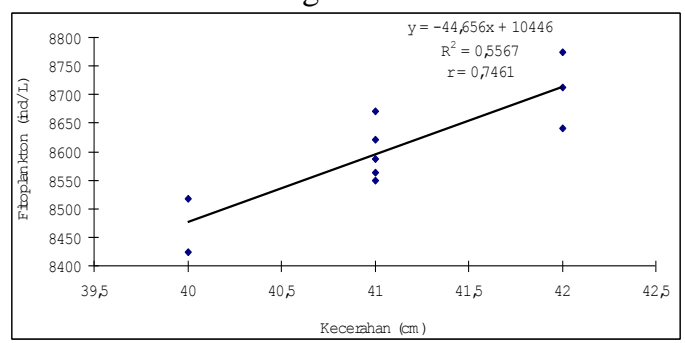

Gambar 3. Regresi linier antara fitoplankton dengan kecerahan

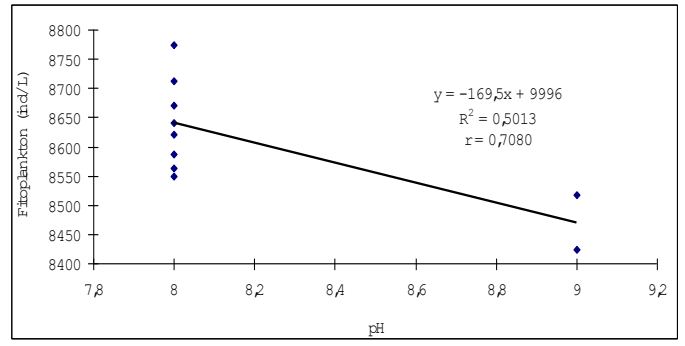

Gambar 4. Regresi linier antara fitoplankton dengan $\mathrm{pH}$

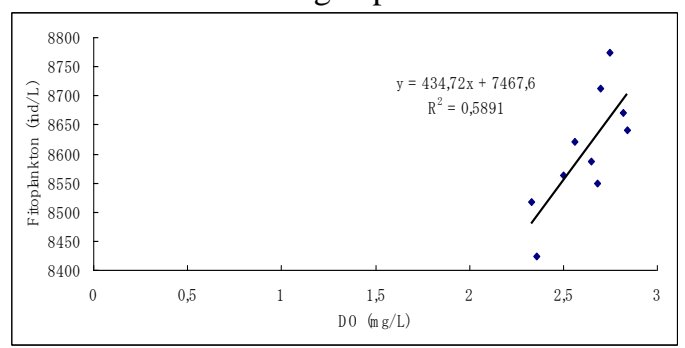

Gambar 5. Regresi linier antara fitoplankton dengan oksigen terlarut

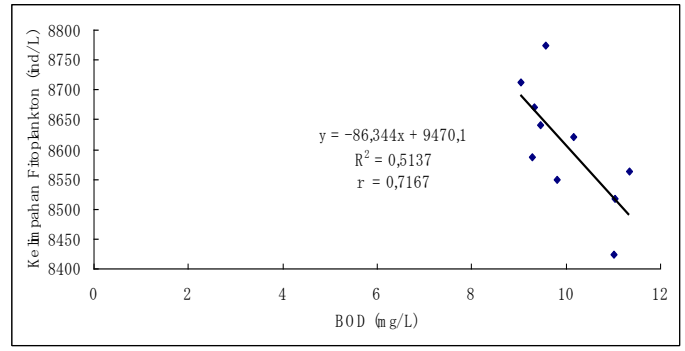

Gambar 6. Regresi linier antara fitoplankton dengan BOD

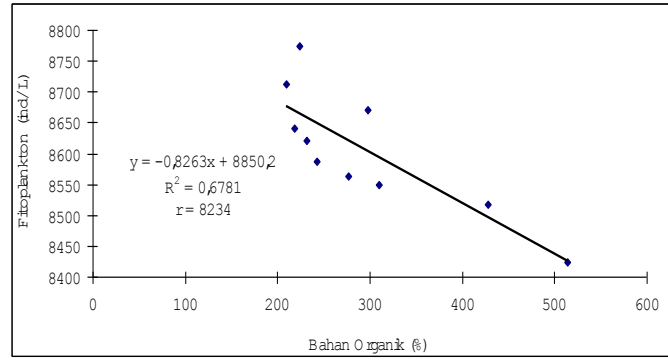

Gambar 7. Regresi linier antara fitoplankton dengan bahan organik

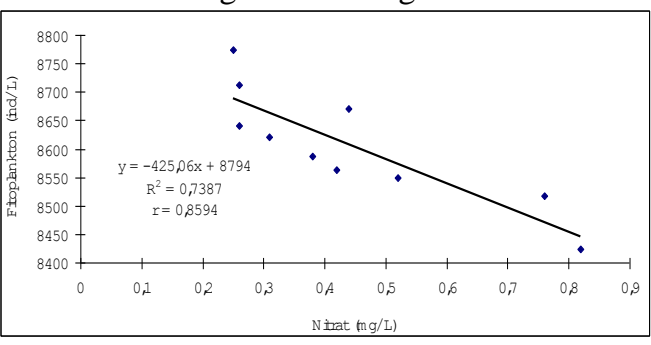

Gambar 8. Regresi linier antara fitoplankton dengan nitrat

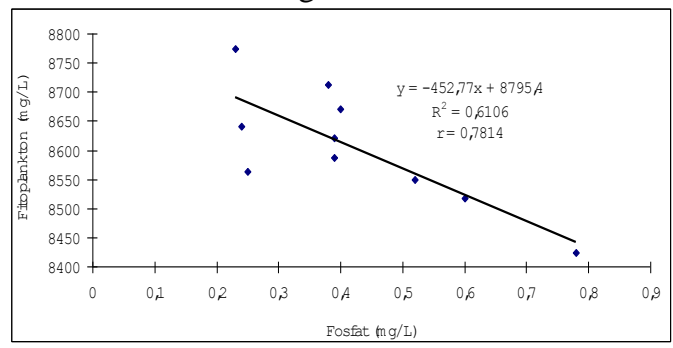

Gambar 9. Regresi linier antara fitoplankton dengan fosfat

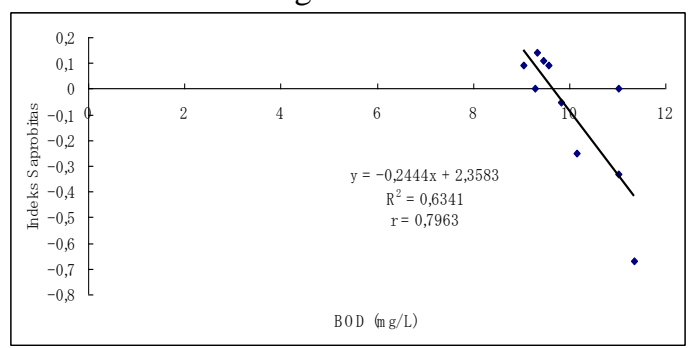

Gambar 10. Regresi linier antara BOD dengan indeks saprobitas

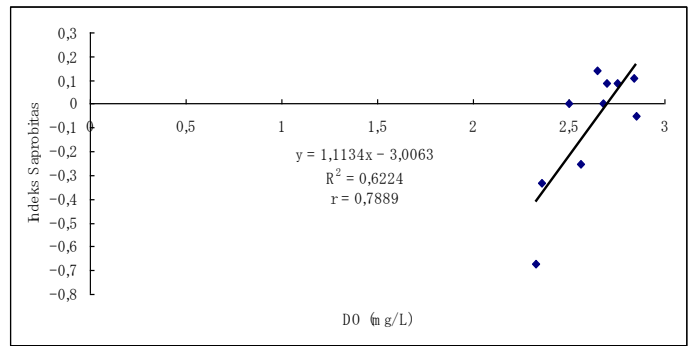

Gambar 11. Regresi linier antara DO dengan indeks saprobitas 



\section{Kesimpulan \\ Kesimpulan}

Berdasarkan hasil penelitian dapat disimpulkan bahwa:

1. Nilai indeks saprobitas berkisar antara $-0,33-0,33$. Sedangkan nilai TSI nya adalah $-0,67-0,42$ yang memberikan indikasi bahwa perairan tergolong kategori $\alpha$-Mesosaprobik (pencemaran sedang sampai berat).

2. Hubungan antara saprobitas perairan dengan variabel BOD menunjukkan adanya korelasi yang kuat $(\mathrm{r}=0,796)$ dengan tingkat keeratan sebesar $63,41 \%$ yang menunjukkan kontribusi pengaruh BOD terhadap saprobitas perairan cukup besar.

3. Hubungan antara saprobitas perairan dengan variabel DO menunjukkan adanya korelasi yang kuat $(r=0,788)$ dengan tingkat keeratan sebesar 62,24\% yang menunjukkan kontribusi pengaruh DO terhadap saprobitas perairan cukup besar.

\section{Daftar Pustaka}

Anggoro, S. 1988. Analisis Tropik-Saprobik (TROSAP) untuk Menilai Kelayakan Lokasi Budidaya Laut. Makalah Workshop Budidaya Laut Perguruan Tinggi Se Jawa Tengah. Tgl 2-4 April di LPWP Jepara.

APHA. 1992. Standard Methods For The Examination of Water and Waste Water. $18^{\text {th }}$ Edition. APHA, AWWA, WEF. Washington DC. $1193 \mathrm{~h}$.

Afrianto, L. dan Liviawati, 1994. Teknik Pembuatan Tambak Udang. Kanisius. Yogyakarta.

Anjas, Asmara. 2005. Hubungan Struktur Komunitas Plankton dengan Kondisi Fisika Kimia Perairan Pulau Pramuka dan Pulau Panggang, Kepulauan Seribu. Departemen Manajemen Sumberdaya Perairan, Fakultas Perikanan dan Ilmu Kelautan Institut Pertanian Bogor. 23-24.

Basmi, J. 2000. Planktonologi : Bioekologi Plankton Algae. Tidak Dipublikasikan Fakultas Perikanan dan Ilmu Kelauan. IPB. Bogor. $110 \mathrm{~h}$.

Dianthani, D. 2003. Identifikasi Jenis Plankton di Perairan Muara Badak, Kalimantan Timur. Makalah Pribadi Pengantar ke Falsafah Sains, Bogor.

Dinas Pengairan Kota Semarang. 2006. Artikel Bau Anyir di Polder Tawang Semarang dikuras. www.bau-air-anyir-polder-tawang-dikuras.htm. Diakses tanggal 4 Maret 2013.

Effendi, H. 2003. Telaah Kualitas Air. Penerbit Kanisius. Yogyakarta.

Hutabarat, S. dan M. Evans. 2000. Pengantar Oceanografi. Penerbit Universitas Indonesia. Jakarta.

Lilik, K. 2005. Kajian Saprobitas Perairan sebagai Landasan Pengelolaan DAS Kaligarang Semarang (Tesis). Program Pascasarjana Universitas Diponegoro, Semarang.

Nybakken, J.M. 1992. Biologi Laut: Suatu Pendekatan Ekologis(diterjemahkan oleh H.M. Eidmar, Koesoebiono, D.G. Bengen, M. Hutomo dan D. Sukardjo). Gramedia. Jakarta.

Odum, P.E. 1971. Fundamental of Ecology $3^{\text {rd }}$. Sounders Company. Philadelphia.

Pringgosaputro, S. 1993. Studi Keterkaitan Antara Aktivitas Pembuangan Limbah Industri Dengan Tingkat Saprobitas di Muara Sungai Sambong Kab. Dati II Batang (Sebagai Upaya Pendugaan Tingkat Pencemaran). Laporan Penelitian. PPLH Lemlit Universitas Diponegoro, Semarang.

Seputar Semarang. 2008. Artikel Polder Tawang Semarang. www.seputarsemarang.com. Diakses tanggal 13 Januari 201

Sudjana, M.A. 1982. Metode Statistik. Publikasi Tarsito. Bandung.

Suryanti. 2008. Kajian Tingkat Saprobitas Di Muara Sungai Morodemak Pada Saat pasang dan Surut. Jurnal Saintek Perikanan,(4) 1:76-83.

Wardoyo, S.T.H. 1982. Kriteria Kualitas Air untuk Keperluan Pertanian dan Perikanan. Dalam : Prosiding Seminar Pengendalian Pencemaran Air. (eds Dirjen Pengairan Dep. PU.), 293-300.

Zahidin. 2008. Kajian Kualitas Air di Muara Sungai Pekalongan diTinjau dari Indeks Keanekaragaman Makrobenthos dan Indeks Saprobitas Perairan (Tesis). Program Pascasarjana Undiversitas Diponegoro. Semarang. 